\title{
Methanol extract of the ethnopharmaceutical remedy Smilax spinosa exhibits anti-neoplastic activity
}

\author{
MAREIKE SEELINGER ${ }^{1}$, RUXANDRA POPESCU ${ }^{2}$, BENEDIKT GIESSRIGL ${ }^{1}$, KANOKWAN JARUKAMJORN $^{3,4}$, \\ CHRISTINE UNGER ${ }^{1}$, BRUNO WALLNÖFER ${ }^{5}$, MONIKA FRITZER-SZEKERES ${ }^{6}$, THOMAS SZEKERES ${ }^{6}$, \\ RENE DIAZ ${ }^{7}$, WALTER JÄGER ${ }^{3}$, RICHARD FRISCH $^{7}$, BRIGITTE KOPP $^{2}$ and GEORG KRUPITZA ${ }^{1}$ \\ ${ }^{1}$ Institute of Clinical Pathology, Medical University of Vienna, Vienna; ${ }^{2}$ Department of Pharmacognosy, Faculty of Life \\ Sciences, University of Vienna, Vienna; ${ }^{3}$ Department of Clinical Pharmacy and Diagnostics, Faculty of Pharmaceutical \\ Sciences, University of Vienna, A-1090 Vienna, Austria; ${ }^{4}$ Department of Pharmaceutical Chemistry, Faculty of \\ Pharmaceutical Sciences, Khon Kaen University, Khon Kaen 40002, Thailand; ${ }^{5}$ Department of Botany, Museum \\ of Natural History, A-1010 Vienna; ${ }^{6}$ Clinical Institute of Medical and Chemical Laboratory Diagnostics, Medical \\ University of Vienna, A-1090 Vienna, Austria; ${ }^{7}$ Institute for Ethno-Biology, Playa Diana, San José/Petén, Guatemala
}

Received March 27, 2012; Accepted May 28, 2012

DOI: $10.3892 /$ ijo.2012.1538

\begin{abstract}
Plants have been the source of several effective drugs for the treatment of cancer and over $60 \%$ of anticancer drugs originate from natural sources. Therefore, extracts of the rhizome of Smilax spinosa, an ethnomedicinal plant from Guatemala which is used for the treatment of inflammatory conditions, were investigated regarding their anti-neoplastic activities. By using several solvents the methanol extract was by far the most potent against HL60 cell proliferation (50\% inhibition at $60 \mu \mathrm{g} / \mathrm{ml})$. Furthermore, fractionation of this extract yielded fraction F2, which exhibited enforced pro-apoptotic activity, and activated CYP1A1. Proteins that are relevant for cell cycle progression and apoptosis, as well as proto-oncogenes were investigated by western blotting. This revealed that the methanol extract increased the levels of p21 and this may have caused cell cycle attenuation. The derivative fraction F2 induced apoptosis through the intrinsic pathway, which correlated with the inhibition of Stat 3 phosphorylation and concomitant induction of caspase 9, then caspase 8 and caspase 3 . In summary, the methanol extract and the derivative fraction F2 of S. spinosa showed anti-neoplastic effects in HL-60 cells and CYP1A1 activation in estrogen receptorpositive MCF-7 breast cancer cells but not in estrogen-negative MDA-MB231 breast cancer cells. Based on our data Smilax spinosa may be a promising source for novel anticancer agents.
\end{abstract}

Correspondence to: Professor Georg Krupitza, Institute of Clinical Pathology, Medical University of Vienna, Waehringer Guertel 18-20, A-1090, Vienna, Austria

E-mail: georg.krupitza@meduniwien.ac.at

Key words: Smilax spinosa, apoptosis, proto-oncogenes, Stat3, $\mathrm{c}-\mathrm{Myc}$

\section{Introduction}

In the western industrialised countries one out of three persons develops some type of cancer during their lifetime (1) and $>50 \%$ of them succumb to the disease (2). For the treatment of many types of cancer, natural products have been the source of effective drugs and today $>60 \%$ of anticancer drugs originate from natural sources such as plants, marine organisms and micro-organisms (3). An estimation conducted by the WHO reveals that even today $80 \%$ of the population of Asia and Africa rely on traditional medicine for primary health care (Traditional Medicine Fact Sheet No. 134, World Health Organization, Dec. 2008, http://www.who.int/mediacentre/ factsheets/fs134/en/).

Fabricant and Farnsworth (4) describe ethnomedicine as a 'highly diversified approach to drug discovery'. It involves observation, description, and experimental investigation of indigenous remedies for their possible biological or medicinal activity. The drugs (of plants mostly) have been used in traditional medicine for hundreds of years, which is the reason why tolerable toxic effects can be expected in humans. Traditional medicine is practiced by shamans or herbalists who keep the healing skills a secret (5) and hence, little is known about their remedies. Therefore, natural products remain an important source for the discovery of new drugs. However, the primary extracts of natural products consist of complex mixtures and this makes the isolation of the active principles a difficult task. The key compounds may be unstable, or the activity may be based on two or more synergistic constituents that may disappear upon separation. Until 2000 (current data are unavailable) only $6 \%$ of higher plant species had been screened for their biologic, mostly anticancer or anti-HIV, activity (4).

Important examples of anticancer drugs derived from an ethnomedicinal plant that are now used in the clinic are the vinca alkaloids vinblastine and vincristine. Both were isolated from the Madagascar periwinkle, Catharanthus roseus G. Don (Apocynaceae). Another agent belonging to the ethno-derived 
chemotherapeutic drugs is paclitaxel isolated from the bark of Taxus brevifolia Nutt. This demonstrates that isolated compounds from plants traditionally used as home remedies may lead to the development of novel anticancer agents (3). Owing to their high biodiversity, rain forests are immensely rich sources for new drugs (6). In particular, ancient civilizations collected knowledge over many hundreds of years regarding the natural products that were effective as therapies against several diseases (7). Combination of these ethnopharmaceutical benefits and the advantageous biodiversity through which the medicinal tradition flourished, established the basis for the present work with the objective of finding new potential lead compounds against cancer by investigating a healing plant of the Maya from the Guatemala/ Belize lowland rainforest. The rhizome of Smilax spinosa Miller (Smilacacea) is used by the indigenous population as a natural remedy against inflammation. We selected this plant to study potential anti-neoplastic properties, as similar signalling pathways are upregulated during inflammation and in cancer cells (8). To date, only a few pharmacological effects of the Smilax species have been investigated in clinical trials (9). For example, Smilax regelii (syn. Sarsaparilla) exhibits antimicrobial activities against Shigella dysenteria (10) and a Smilax glabra extract had immuno-modulatory activity in rats by decreasing the IL-1-, TNF- and NO-release of macrophages (11). S. regelii is mostly applied internally against arthritis, rheumatism (both causing inflammation), psoriasis or dermatitis (skin disorders), impotence, or as a blood purifier (9). It is described to be active against snake bites (12) but an excessive dosage of $S$. regelii has been reported to cause gastrointestinal irritation (9). Smilax species are particularly known to contain saponins and plant steroids that can be synthesized into human steroids such as estrogen and testosterone. Also, the majority of $S$. regelii's activities are reported to be caused by these steroids and saponins (9). The methanol extract of $S$. spinosa renders DPPH, OH, and O2-radicals innocuous thereby inhibiting lipid peroxidation. Furthermore, it was effective against Salmonella typhimurium and Trypanosoma cruzii. Therefore, the methanol extract has an anti-oxidative and anti-microbial activity (13). When used against male impotency, $S$. spinosa rhizome and guinweo (a local plant) are soaked in rum and administered twice a day (14). Already in 1536 a Smilax root from Mexico was introduced into European medicine to treat syphilis and rheumatism (9). As $S$. spinosa has not yet been investigated for its anti-neoplastic activity, the present study was conducted to analyse its antiproliferative effects.

\section{Materials and methods}

Antibodies. Antibodies against: cleaved Asp175 caspase3 (no. 9661), cleaved caspase 8 (Asp391, 18C8, no. 9496), cleaved caspase 9 (Asp330, no. 9501), phospho-Stat3 (Tyr705)(D3A7, no. 9145), Stat3 (no. 9132) and phospho-Stat5 (Tyr694)(C11C5, 9359) were from Cell Signaling (Danvers, MA, USA). PARP-1 (F-2, sc-8007), Cdc25A (F-6, sc-7389), cyclin D1 (M-20, sc-718), p21 (C-19, sc-397), $\alpha$-tubulin (DM1A, sc-32293), $\beta$-tubulin (H-235, sc-9104), Stat5 (C-17, sc-835), c-Jun (H-79, sc-1694) and Jun B (210, sc-73) were obtained from Santa Cruz Biotechnology (Santa Cruz, CA, USA). c-Myc Ab-2 (9E10.3,
Table I. Solvents used for extraction of S. spinosa and extract weights.

Extract weight $(\mathrm{mg})$
corresponding to
$1 \mathrm{~g}$ dried rhizome

Petroleum ether 0.7

Dichloromethane 1.1

Ethyl acetate

11.1

Methanol

205.5

Water

147.8

no. MS-139-P1) was from Thermo Fisher Scientific (Fremont, CA, USA), phospho- Ser177 Cdc25A (no. AP3046a) from Abgent (San Diego, CA, USA), phospho-Ser139 H2AX (DR 1017) from Calbiochem (San Diego, CA, USA) and $\beta$-actin (AC-15, A5441) as well as anti-acetylated tubulin (clone611B-1, T6793) were from Sigma (St. Louis, MO, USA). The secondary antibodies peroxidase-conjugated anti-rabbit IgG and anti-mouse IgG were purchased from Dako (Glostrup, Denmark).

Cell culture. HL-60 (human promyelocytic leukaemia) cells and human MCF-7 and MDA-MB231 breast cancer cell lines were purchased from American Type Culture Collection (ATCC, Rockville, MD, USA) and grown in RPMI-1640 medium (HL-60). The other cell lines were grown in MEM medium, which was supplemented with $10 \%$ heat-inactivated foetal calf serum (FCS), $1 \%$ Glutamax and 1\% penicillin/ streptomycin (Life Technologies, Carlsbad, CA, USA), $1 \%$ NEAA (Invitrogen, Karlsruhe, Germany). Cells were kept in a humidified atmosphere at $37^{\circ} \mathrm{C}$ containing $5 \% \mathrm{CO}_{2}$.

Plant material. Parts of the rhizomes of Smilax spinosa Miller (vernacular name: 'Kokolmeka roja') were collected in Guatemala, Departamento Petén, at the north-western shore of Lago Petén Itzá, San José, $\sim 1 \mathrm{~km}$ north of the road from San José to La Nueva San José (16 59'30" N, 89 54'00" W). Voucher specimens (leg. G. Krupitza and R. O. Frisch, Nr. 4-2009, 19. 04. 2009, Herbarium W, det. B. Wallnöfer (W) 26.1.2010) were archived at the Museum of Natural History, Vienna, Austria.

Extraction. Rhizomes of S. spinosa were cut, dried by lyophilisation and then pulverized. Twenty grams of the obtained powder were mixed with $200 \mathrm{ml}$ solvent (1:10; Table I) extracted in an ultra sonic bath for $10 \mathrm{~min}$ and afterwards under reflux for $1 \mathrm{~h}$ in the water bath. The solution was filtered and the retained plant material (residue) was dried at room temperature before being re-extracted with the next more polar solvent. The liquid extract was evaporated under reduced pressure to give a crude fraction $(0.67 \mathrm{mg}$ corresponding to $1 \mathrm{~g}$ rhizome; Table I) $(15,16)$. The extract weights obtained from serial extraction of the dried rhizomes of S. spinosa with five solvents of increasing polarity are presented in Table I, which illustrates that the weight of the methanol extract corresponds to $\sim 20.6 \%$ of the dried rhizome. 
Table II. Obtained amounts of sub-fractions derived from $4.1 \mathrm{~g}$ of methanol extract.

Fraction

FI Petroleum ether

F2 Water-methanol

F3 Chloroform
Potentially abundant substances

Amount (g)

Chlorophyll, wax, resin

0.03

less polar compounds

Tannins, more polar substances

3.65

Chloroform-soluble substances
Sub-fractionation of the methanol extract. The methanol extract was the most active of the $S$. spinosa extracts, therefore it was further fractionated by dissolving $4.1 \mathrm{~g}$ in $60 \mathrm{ml}$ of a water-methanol mixture (9:1). After threefold extraction with $60 \mathrm{ml}$ petroleum ether each for the removal of chlorophyll, waxes and fats, the remaining fraction was diluted with $60 \mathrm{ml}$ of water. Subsequently, this aqueous solution was extracted three times with $120 \mathrm{ml}$ chloroform each. The collected chloroform layers were washed three times with $360 \mathrm{ml}$ sodium chloride solution (1\%). After drying with sodium sulphate, the solution was filtered and the chloroform was evaporated under reduced pressure. The weights of the obtained sub-fractions are listed in Table II. Approximately $10 \%$ of the starting extract was lost during the fractionation process.

Thin layer chromatography with chloroform: methanol: water (70:22:3.5) revealed that the petroleum ether fraction (F1) exhibited an almost identical banding pattern as the petroleum ether extract (detection under visible light and UV366 with ASR; data not shown), but with some additional bands, which seemed to be responsible for the higher activity of the F1 fraction (data not shown) compared to the petroleum ether extract.

Proliferation and cytotoxicity assays. HL-60 cells were seeded in 24-well plates at a concentration of $1 \times 10^{5}$ cells $/ \mathrm{ml}$ allowing logarithmic growth within the next $48 \mathrm{~h}$. Cells were then incubated with increasing concentrations of plant extracts $(5 \mu \mathrm{g} / \mathrm{ml}, 15 \mu \mathrm{g} / \mathrm{ml}, 30 \mu \mathrm{g} / \mathrm{ml}, 60 \mu \mathrm{g} / \mathrm{ml})$ for $48 \mathrm{~h}$. After 24 and $48 \mathrm{~h}$, the cell number was counted using a KX-21 N microcell counter (Sysmex Corporation, Kobe, Japan) and the percent of cell divisions compared to the untreated control were calculated as follows: $[(\mathrm{C} 48 \mathrm{~h}+\mathrm{drug}-\mathrm{C} 24 \mathrm{~h}+\mathrm{drug}) /(\mathrm{C} 48 \mathrm{~h}-\mathrm{drug}$ - $\mathrm{C} 24 \mathrm{~h}$ - drug)] x 100=\% cell division, whereby $\mathrm{C} 48 \mathrm{~h}+$ drug or $\mathrm{C} 48 \mathrm{~h}$ - drug were the cell numbers after $48 \mathrm{~h}$ with or without extract treatment, respectively. C24h + drug or C24h - drug were the respective cell numbers after $24 \mathrm{~h}(17,18)$.

Apoptosis assay - Hoechst 33258 and propidium iodide double staining. Hoechst 33258 (HO) and propidium iodide (PI) double staining (Sigma, St. Louis, MO) determine the type of death the cell is undergoing, i.e. apoptosis (early or late) or necrosis $(19,20)$. HL-60 cells were seeded in a 24-well plate at a concentration of $1 \times 10^{5}$ cells $/ \mathrm{ml}$ and treated with increasing concentrations of fractions F1, F2 and F3. After $24 \mathrm{~h}, 48 \mathrm{~h}$ and $72 \mathrm{~h}$ of incubation, $100 \mu \mathrm{l}$ cell suspension of each well was transferred into separate wells of a 96-well plate and $\mathrm{HO}$ and PI were added at final concentrations of $5 \mu \mathrm{g} / \mathrm{ml}$ and $2 \mu \mathrm{g} / \mathrm{ml}$, respectively. After $1 \mathrm{~h}$ of incubation at $37^{\circ} \mathrm{C}$, stained cells were examined and photographed on a fluorescence microscope
(Axiovert, Zeiss, Jena, Germany) equipped with a DAPI filter. Cell death was evaluated and counted by visual examination of the photographs according to the morphological characteristics revealed by HOPI staining. Experiments were performed in triplicate.

Western blotting. HL-60 were seeded in T-75 tissue culture flasks at a concentration of $1.8 \times 10^{5}$ cells $/ \mathrm{ml}$ and treated with the indicated concentration of methanol extract or fraction F2. Cells were harvested after $0.5,2,4,8$ and $24 \mathrm{~h}$. Then, cells were washed twice with cold PBS and centrifuged at 1,000 rpm for $5 \mathrm{~min}$ at $4^{\circ} \mathrm{C}$. The cell pellet was lysed in a buffer containing $150 \mathrm{mM} \mathrm{NaCl}, 50 \mathrm{mM}$ Tris $\mathrm{pH}$ 8.0, 1\% Triton-X-100, $1 \mathrm{mM}$ phenylmethylsulfonyl fluoride (PMSF) and $1 \mathrm{mM}$ Protease Inhibitor Cocktail (PIC), (Sigma, Schnelldorf, Germany). The lysate was centrifuged at $12,000 \mathrm{rpm}$ for $20 \mathrm{~min}$ at $4^{\circ} \mathrm{C}$. Supernatant was transferred into a $1.5 \mathrm{ml}$ tube and stored at $-20^{\circ} \mathrm{C}$ until further analysis. Equal amounts of protein lysate were mixed with SDS (sodium dodecyl sulphate) sample buffer and loaded onto a $10 \%$ polyacrylamide gel. Proteins were separated by polyacrylamide gel electrophoresis (PAGE) at 120 Volt and electro-transferred onto a PVDF (polyvinylidene difluoride) membrane (Hybond, Amersham, Buckinghamshire, UK) at 95 Volt for $80 \mathrm{~min}$. Membranes were allowed to dry for at least $30 \mathrm{~min}$ up to $2 \mathrm{~h}$ to provide fixing of the proteins to the membrane. Methanol was used to remoisten the membranes. Equal sample loading was checked by staining the membrane with Ponceau S (Sigma, Schnelldorf, Germany). After removing Ponceau S with PBS or TBS (Tris buffered saline, pH 7.6), membranes were blocked in PBS- or TBS-milk (5\% non-fat dry milk in PBS containing $0.5 \%$ Tween-20 or TBS containing $0.1 \%$ Tween-20) for $1 \mathrm{~h}$. Then, membranes were washed with PBS/T (PBS containing $0.5 \%$ Tween-20) or TBS/T (TBS containing $0.1 \%$ Tween-20), changing the washing solution 4-5 times, for at least $20 \mathrm{~min}$. Next, membranes were incubated with the primary antibody in blocking solution (according to the data sheet TBS-, PBS-milk or TBS-, PBS-BSA) diluted 1:500 - 1:1000, gently shaking at $4^{\circ} \mathrm{C}$, overnight. Thereafter, membranes were washed again with PBS/T or TBS/T and incubated with the secondary antibody (peroxidase conjugated anti-rabbit IgG or anti-mouse IgG) diluted 1:2000 in PBS- or TBS-milk at room temperature for $1 \mathrm{~h}$. Chemiluminescence was developed by the ECL detection kit (Amersham, Buckinghamshire, UK) and membranes were exposed to Amersham Hyperfilm.

Ethoxyresorufin-O-deethylase (EROD) assay selective for CYP1A1 activity. MDA-MB-231 and MCF-7 breast cancer cells were grown in phenol red-free DMEM/F12 culture 

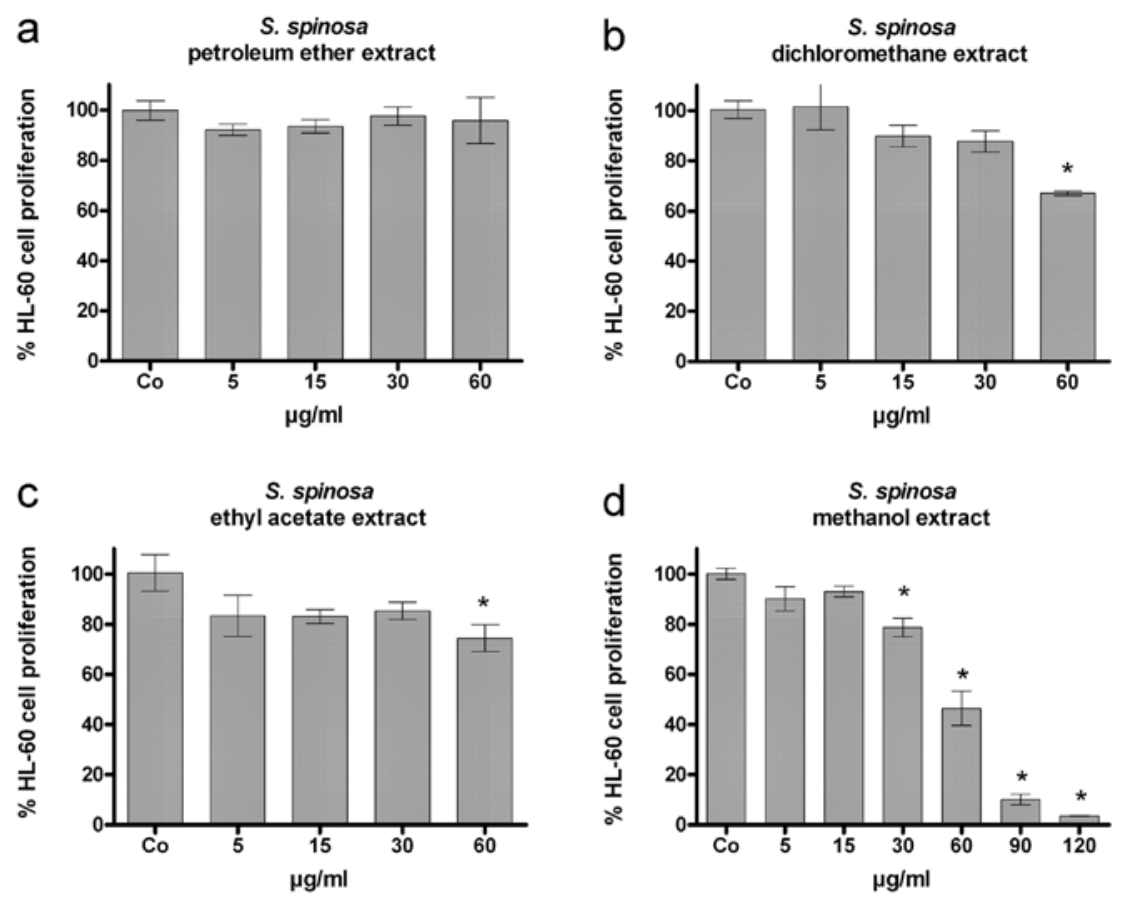

e

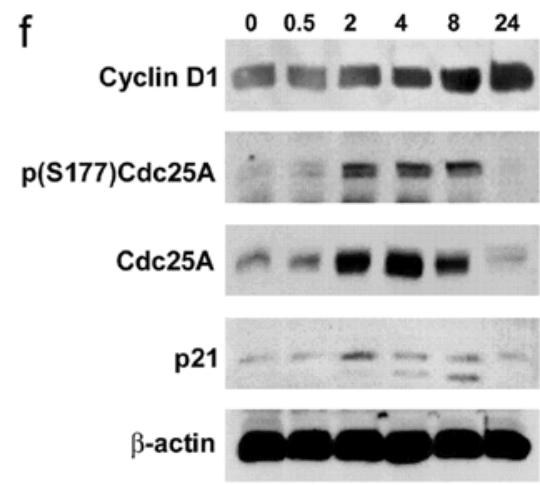

Figure 1. Anti-proliferative effect of increasingly polar extracts; (a) petroleum ether, (b) dichloromethane, (c) ethyl acetate, (d) methanol, and (e) water). HL-60 cells were seeded into 24 -well plates $\left(1 \times 10^{5}\right.$ cells/ml), incubated with 5, 15, 30 and $60 \mu \mathrm{g} / \mathrm{ml}$ of each extract (the methanol extract also with 90 and $120 \mu \mathrm{g}$ ) for $48 \mathrm{~h}$. Cells were counted after 24 and $48 \mathrm{~h}$ of treatment. The percentage of proliferation between 24 and $48 \mathrm{~h}$ was determined in comparison to control. Experiments were performed in triplicate. Asterisks indicate significance compared to untreated control $(\mathrm{p}<0.05)$ and error bars indicate the means \pm SEM. (f) Analysis of the expression of cell cycle regulators. HL-60 cells $\left(1 \times 10^{6} \mathrm{cell} / \mathrm{s} / \mathrm{ml}\right)$ were incubated with $120 \mu \mathrm{g} / \mathrm{ml}$ of the methanol extract and harvested after $0.5,2,4,8$ and $24 \mathrm{~h}$ of treatment. Cells were lysed and the obtained protein samples were subjected to SDS-gel electrophoresis and subsequent western blot analysis with the indicated antibodies. Equal sample loading was confirmed by Ponceau S staining and $\beta$-actin analysis.

medium (Invitrogen, Karlsruhe, Germany) supplemented with $10 \%$ FCS and $1 \%$ PS (Invitrogen, Karlsruhe, Germany) under standard conditions at $37^{\circ} \mathrm{C}$ in a humidified atmosphere containing $5 \% \mathrm{CO}_{2}$ and $95 \%$ air. Twenty-four hours prior to treatment, the cells were transferred to DMEM/F12 culture medium supplemented with $2.5 \%$ charcoal-stripped FCS (PAN Biotech, Aldenbach, Germany) and 1\% PS. The MeOH extract and F2 were dissolved in DMSO and diluted with medium (final DMSO concentration $<0.1 \%$ ) to 30 and $60 \mu \mathrm{g} / \mathrm{ml}$. Experiments under each set of conditions were carried out in triplicate. Blanks contained DMSO in the medium of the test compounds. After $18 \mathrm{~h}$ of incubation, ethoxyresorufin (final concentration 5.0 $\mu \mathrm{M}$, Sigma-Aldrich, Munich, Germany) was added and $0.4 \mathrm{ml}$ aliquots of the medium were sampled after $200 \mathrm{~min}$. Subsequently, the formation of resorufin was analyzed by spectrofluorometry (PerkinElmer LS50B, Waltham, MA,
USA) with an excitation wavelength of $530 \mathrm{~nm}$ and an emission wavelength of $585 \mathrm{~nm}$.

Statistical analysis. For statistical analyses Excel 2003 software and Prism 5 software package (GraphPad, San Diego, CA, USA) were used. The values are expressed as the mean \pm SEM and the Student's t-test was applied to compare differences between control samples and treatment groups. Statistical significance level was set at $\mathrm{p}<0.05$.

\section{Results and Discussion}

The lyophilized rhizome of $S$. spinosa was subjected to sequential extraction with five solvents of increasing polarity. The obtained extracts were investigated for their anti-neoplastic potential in HL-60 leukaemia cells, as blood 
a

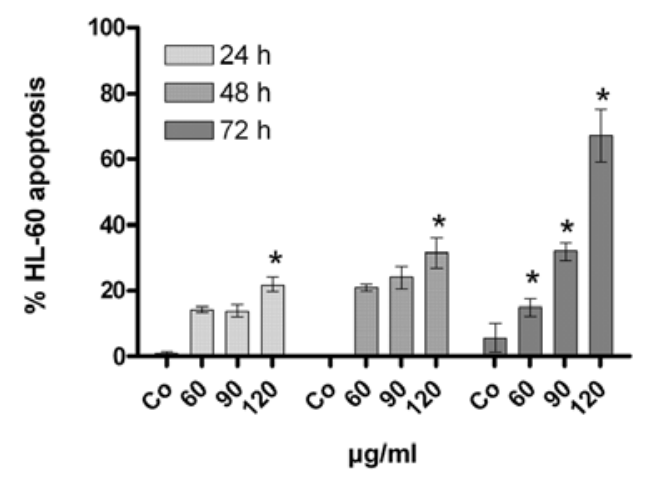

b

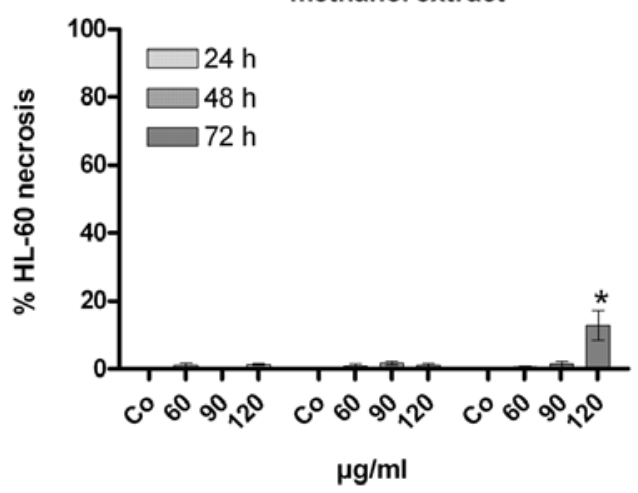

Figure 2. Induction of cell death. HL-60 cells were seeded in 24 -well plates (1x10 5 cells $/ \mathrm{ml})$ and incubated with 60,90 and $120 \mu \mathrm{g} / \mathrm{ml}$ methanol extract for 24,48 , and $72 \mathrm{~h}$. Then, cells were double stained with Hoechst 33258 and propidium iodide and examined under the microscope with UV light connected to a DAPI filter. Nuclei with morphological changes which indicated (a) apoptosis or (b) necrosis were counted and the percentage of apoptotic or necrotic cells was calculated. Experiments were performed in triplicate. Asterisks indicate significance compared to untreated control $(\mathrm{p}<0.05)$ and error bars indicate the means \pm SEM.

cells are easily accessible and sensitive to pharmacological compounds, thereby providing an appropriate system for an initial testing series.

Inhibition of cell proliferation. To determine the anti-proliferative effects in HL-60 cells, extracts were applied at increasing concentrations $(5,10,30,60 \mu \mathrm{g} / \mathrm{ml}$ and partly 90 and $120 \mu \mathrm{g} / \mathrm{ml})$ for 24,48 , and $72 \mathrm{~h}$ (Fig. 1a-e). The methanol extract was the most potent and inhibited cell proliferation dose-dependently with an $\mathrm{IC}_{50}$ (the concentration inhibiting $50 \%$ proliferation) of $\sim 60 \mu \mathrm{g} / \mathrm{ml}$. The extract exhibited the highest activity within the first $48 \mathrm{~h}$, which decreased thereafter (data not shown). Although the extract concentration at which proliferation was significantly inhibited was rather high, the corresponding weight of the rhizome was low, as the methanol extract was almost one fifth of the whole lyophilized rhizome substance. This corresponds to $300-500 \mathrm{mg}$ of dried rhizome, or 370-630 mg of fresh rhizome per kg body weight; a person with an average body weight has to consume the alcoholic extract derived from only $20 \mathrm{~g}$ of rhizome within two days. Inhibition of cell proliferation was accompanied by a rapid upregulation of Cdc25A expression within $2 \mathrm{~h}$ of treatment (Fig. 1f). It seems that the high Cdc25A levels were the result of an increased protein synthesis rather than an inhibited protein degradation, as Ser177 phosphorylation, which tags Cdc25A for recruitment of the proteasome and subsequent proteolysis (21), was sustained throughout 2 and $8 \mathrm{~h}$ of treatment, whereas the degradation of the Cdc25A proto-oncogene below control levels was observed after $24 \mathrm{~h}$. The increase in Cdc25A was followed by cyclin D1 upregulation within $4 \mathrm{~h}$. The protooncogene cyclin D1 is necessary for the transit from early G1 to beginning of $\mathrm{S}$ phase and induction of cyclin D1 expression is indicative for cell cycle activation. p21 inhibits the Cdk2/ Cyclin E kinase complex that normally cooperates with cyclin D1 at a later stage to facilitate G1-S transition and then S-phase progression (22). p21 was induced within $2 \mathrm{~h}$ of extract treatment and this accurately counteracted the induction of $\mathrm{Cdc} 25 \mathrm{~A}$ phosphatase, which causes the activation of $\mathrm{Cdk} 2 / \mathrm{Cyclin} \mathrm{E}$. $(23,24)$ and therefore, cell cycle progression was blocked. Additionally, p21 binds to the Cdk4/Cyclin D complex. This results in a hypo-phosphorylation and activation of $\mathrm{pRb}$ and thereby the suppression of the E2F pathway and cessation of the cell cycle (25). However, when cyclin D1 became induced, p21 levels were already back to control levels. An additional band below $21 \mathrm{kD}$ became visible, which was most likely a degradation product of p21. Expression of p21 transcription is widely regulated by p53. Since HL-60 cells are p53 deficient (26) p21 must have been controlled in a p53-independent manner (27) and it was shown that the proto-oncogene c-Myc negatively regulates p21 (28). The chaotic expression of prominent cell cycle protagonists and proto-oncogenes together with p21 induction undoubtedly affected DNA replication and cell duplication thereby triggering growth arrest.

Induction of apoptosis. Growth arrest due to extra-cellular stressors often elicits apoptosis. Therefore, HL-60 cells were treated with increasing concentrations $(60,90,120 \mu \mathrm{g} / \mathrm{ml})$ of the methanol extract to analyse cell viability (Fig. 2a). The time- and dose-dependent increase in the number of dead cells showed a morphology which is typical for apoptosis, whereas a small number of necrotic cells were only observed at the highest dose $(120 \mu \mathrm{g} / \mathrm{ml})$ after $72 \mathrm{~h}$ (Fig. 2b). In an attempt to increase the pro-apoptotic activity the methanol extract was subjected to a fractionation procedure (as described in Materials and methods) obtaining three fractions. Fraction 2 (F2) exhibited the strongest pro-apoptotic effect whereby $40 \%$ apoptotic cells were observed upon treatment with $90 \mu \mathrm{g} / \mathrm{ml}$ $\mathrm{F} 2$ for $24 \mathrm{~h}$ (Fig. 3a) and this was a 2.5 fold increase compared to the primary methanol extract $(<15 \%$ apoptotic cells upon treatment with $90 \mu \mathrm{g} / \mathrm{ml}$ methanol extract for $24 \mathrm{~h}$; Fig. 2a). F2 inhibited cell proliferation less efficiently than the original methanol extract (data not shown). Therefore, a cell cycle inhibitory property was separated from a pro-apoptotic property which was less dependent on the cell cycle. This is of particular significance as tumour cells, which are not cycling, could be targeted by this fraction. To get further insight into the mechanisms of F2, the expression of pro-apoptotic proteins as well as of markers indicating genotoxicity and microfilament stress was investigated. The increased cleavage of caspase 9 was observed after $2 \mathrm{~h}$ of incubation, whereas caspase 8 was 
a

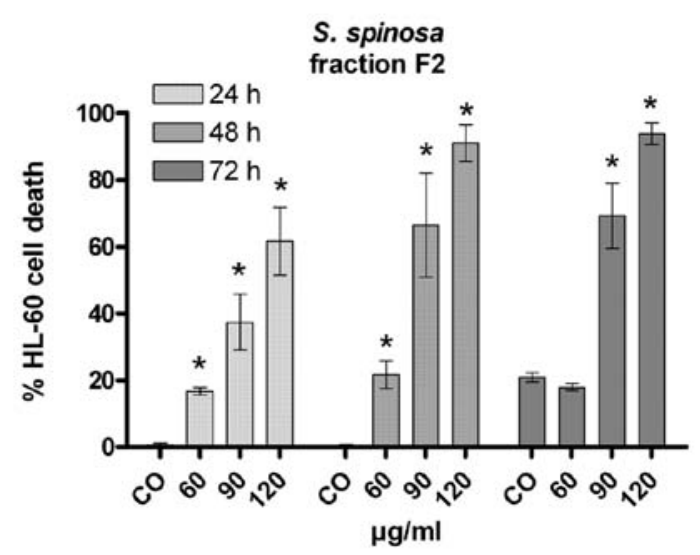

b
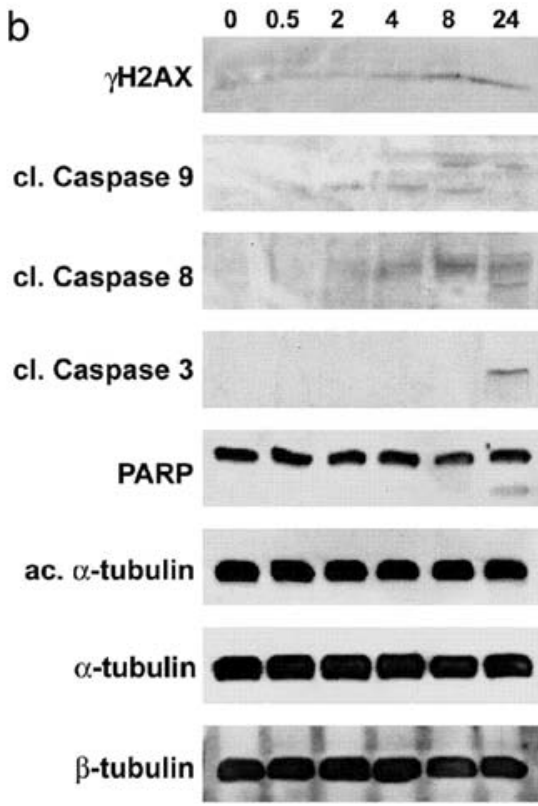

Figure 3. (a) Induction of apoptosis by fraction F2 water-methanol fraction. HL-60 cells were seeded in 24 -well plates (1x10 5 cells/ml) and incubated with 60 , 90 and $120 \mu \mathrm{g} / \mathrm{ml}$ of each extract for 24, 48, and $72 \mathrm{~h}$. Afterwards cells were double stained with Hoechst 33258 and propidium iodide and examined under the microscope with UV light connected to a DAPI filter. Nuclei with morphological changes which indicated apoptosis were counted and the percentage of apoptotic cells were calculated. Experiments were performed in triplicate. Asterisks indicate significance compared to untreated control ( $<<0.05$ ) and error bars indicate the means \pm SEM. (b) Analysis of the expression of apoptosis related proteins. HL- 60 cells $\left(1 \times 10^{6}\right.$ cells $\left./ \mathrm{ml}\right)$ were incubated with $120 \mu \mathrm{g} / \mathrm{ml}$ of fraction F2 and harvested after $0.5,2,4,8$ and $24 \mathrm{~h}$ of treatment. Cells were lysed and the obtained protein samples were subjected to SDS-gel electrophoresis and subsequent western blot analysis was conducted with the indicated antibodies. Equal sample loading was confirmed by Ponceau S staining and $\beta$-tubulin analysis.

cleaved after $4 \mathrm{~h}$. Finally the executor, caspase 3, was activated after $24 \mathrm{~h}$. The caspase cascade i.e. the activation of caspase 9 and 8 , which both cause the cleavage and activation of caspase 3 and the subsequent induction of apoptosis (2) suggested that F2 induced the intrinsic pathway. The activity of caspase 3 was reflected by the cleavage of its target PARP $(120 \mathrm{kD})$ into a smaller $85 \mathrm{kD}$ fragment (29) (Fig. 3b). The phosphorylation of $\mathrm{H} 2 \mathrm{AX}(\gamma \mathrm{H} 2 \mathrm{AX})$ is a sensitive and commonly used marker for the presence of DNA-double-strand breaks (30). During this experiment, the phosphorylation of $\mathrm{H} 2 \mathrm{AX}$ was induced after 8 and 24 h, whereas caspase 9 was activated before phosphorylation of $\mathrm{H} 2 \mathrm{AX}$ implicating that the increase of $\gamma \mathrm{H} 2 \mathrm{AX}$ levels was the consequence of caspase 3 activation and the subsequent induction of nucleases causing DNA degradation. Therefore, F2 itself did not induce DNA double strand breaks but this does not exclude the possibility of a genotoxic property of F2 triggering DNA single strand breaks or the generation of DNA adducts.

Several plant compounds were shown to affect the equilibrium of microtubule polymerization. Tilting this fine-tuned equilibrium of polymerized-depolymerized microfilaments is incompatible with normal cell division and causes cell cycle arrest and apoptosis. The acetylation of $\alpha$-tubulin reflects the polymerization status of the microtubule meshwork (31). However, F2 did not alter tubulin acetylation and therefore did not target the spindle apparatus.

Modulated expression of the proto-oncogenes Stat3, c-Myc and $c$-Jun. Stat family proteins are transcription factors involved in normal and pathological cellular processes. The Stat3 proto-oncogene product is the most activated Stat protein in $\begin{array}{llllll}0 & 0.5 & 2 & 4 & 8 & 24\end{array}$

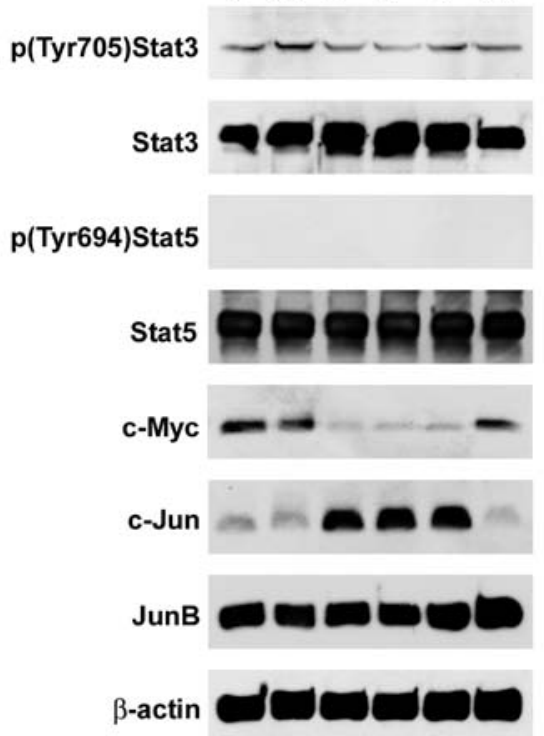

Figure 4. Analysis of proto-oncogene expression. HL- 60 cells $\left(1 \times 10^{6}\right.$ cells $\left./ \mathrm{ml}\right)$ were incubated with $120 \mu \mathrm{g} / \mathrm{ml}$ of the methanol extract and harvested after $0.5,2,4,8$ and $24 \mathrm{~h}$ of treatment. Cells were lysed and the obtained protein samples were subjected to SDS-gel electrophoresis and subsequent western blot analysis with the indicated antibodies. Equal sample loading was confirmed by Ponceau $S$ staining and $\beta$-actin analysis.

human cancers (32) accelerating cell proliferation, preventing apoptosis (33) and playing a role in angiogenesis (34). Stat3, which is phosphorylated at Tyr 705, shifts into the nucleus activating target genes (35) and overexpression of Stat 3 was found 


\section{CYP1A1 activity in MCF-7 cells}

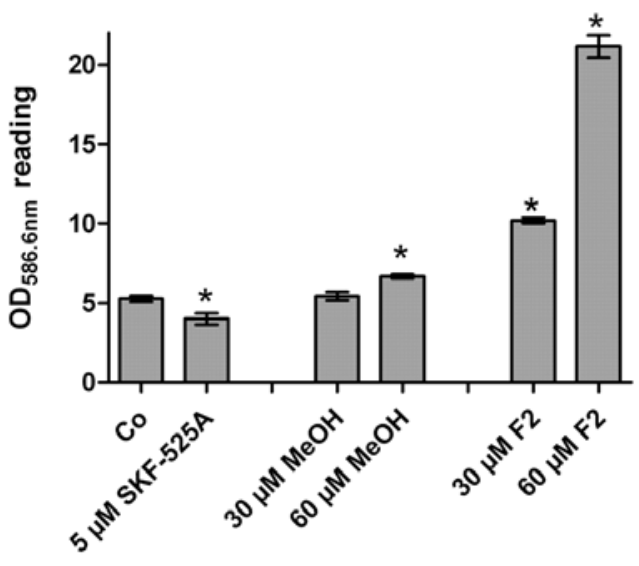

CYP1A1 activity in MDA-MB231 cells

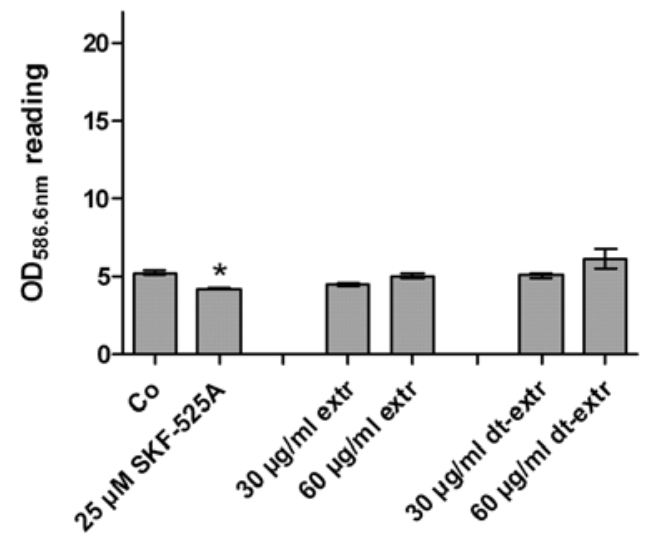

Figure 5. Induction of CYP1A1 activity in breast cancer cells. (a) MCF-7 and (b) MDA-MB231 cells were kept under steroid-free conditions and treated with $30 \mu \mathrm{g} / \mathrm{ml}$ and $60 \mu \mathrm{g} / \mathrm{ml}$ S. spinosa crude $\mathrm{MeOH}$ extract, fraction F2, solvent (DMSO; Co) or $5 \mu \mathrm{M}$ and $25 \mu \mathrm{M}$ CYP inhibitor SKF-525A. Then, $5 \mu \mathrm{M}$ ethoxyresorufin was added and after $200 \mathrm{~min}$ the formation of resorufin was analysed, which is specific for CYP1A1 activity. Experiments were performed in triplicate, error bars indicate SEM and the asterisks indicate $(\mathrm{p}<0.05)$.

in leukaemia, breast, pancreatic and prostate cancer, as well as in melanoma (36). In F2-treated HL-60 cells the constitutive Tyr 705 phosphorylation of Stat 3 was downregulated after $2 \mathrm{~h}$ (Fig. 4) which suggests that the anti-apoptotic activity was also decreased temporally correlating with the activation of caspase 9. Also, the Stat5 proto-oncogene induces antiapoptotic genes such as Bcl-X (37), thereby maintaining cell survival despite drug-induced stresses (38). However, Stat5 was neither constitutively phosphorylated (activated) nor was the protein level decreased by F2. By contrast, the expression of c-Myc was strongly suppressed after $2 \mathrm{~h}$ of $\mathrm{F} 2$ treatment and was re-expressed (still below control levels) after 24 h. c-Myc causes an abnormal proliferation rate and is overexpressed in many tumour types and influences cell differentiation and apoptosis (39).

c-Jun and JunB belong to the family of Jun transcription factors, which are components of the activating protein-1 (AP1) transcription factor complexes. AP1 heterodimers are important for cell proliferation, differentiation, and activated c-Jun promotes cell cycle progression and neoplastic transformation (40). Markedly, c-Jun was strongly increased between 2 and 8 h of F2 treatment, whereas JunB expression remained unchanged. The strictly inverse expression of c-Jun and c-Myc upon F2 treatment was most likely independent of each other, as it has not been reported that c-Jun and the AP1 complex suppress c-Myc, nor has it been shown that c-Myc negatively regulates c-Jun. However, when in complex with ATF2 and c-Myc, c-Jun binds to the ATF/CRE site of ATF3 and c-Jun/ ATF2/c-Myc induce cell proliferation (41). The dramatic disproportional expressions of c-Myc and c-Jun upon F2 treatment excluded the possibility of a transcriptional active c-Myc/ ATF2/c-Jun complex and hence, in case of such a scenario, proliferation was most likely compromised.

Induction of CYPIA1 activity in MCF-7 cells. Smilacacea species are reported to contain steroidal compounds with estrogenic and anti-estrogenic effects $(42,43)$. A subset of cytochrome P450 (CYP) enzymes are important regulators of estrogen and phyto-estrogen metabolism and CYP1A1 plays a role in estrogen receptor (ER) pathway-dependent synergic carcinogenic action of xeno-estrogens (44). Caucasian individuals with polymorphic CYP1A1 (homozygous for A2455G) stand an increased risk for breast cancer $(45,46)$. Therefore, we analysed the activity of CYP1A1 on $S$. spinosa extract treatment in ER positive (MCF-7) and ER negative (MDA-MB231) breast cancer cell lines (Fig. 5). In MCF-7 cells the crude $\mathrm{MeOH}$ extract weakly induced CYP1A1, whereas CYP1A1 was severely induced by F2. This effect was not observed in MDA-MB231 cells. CYP1A1 inhibition augments LPS-triggered fever, whereas induction of CYP1A1 controls fever and inhibits inflammation $(47,48)$. This seems to depend on the expression of ER and suggests that this remedy is particularly effective in women and could explain its use against internal haemorrhaging during menstruation or after childbirth (14). CYPs are phase 1 enzymes and detoxify xenobiotics and contribute to drug clearance but they also activate pro-carcinogens. Therefore, it has to be considered that the intake of this remedy can cause unwanted interactions with other drugs or environmental (nutritional) compounds.

Conclusion. Among different extracts of increasing polarity the methanol extract of the rhizome of S. spinosa inhibited cell proliferation most significantly, which was associated with the induction of $\mathrm{p} 21$. The induction of the proto-oncogenes Cdc25A and cyclin D1 may have counteracted cell cycle arrest, yet they did not prevent it. Further fractionation of the methanol extract increased the apoptotic property $(\sim 2.5$ fold at $60 \mu \mathrm{g} / \mathrm{ml})$, which correlated with the transient inactivation of the proto-oncogene Stat 3 and the activation of caspase 9, followed by the induction of caspase 8 and 3. Overexpression of c-Jun did not abrogate, but most likely attenuated apoptosis. Reportedly, the mere overexpression of proto-oncogenes can trigger apoptosis when other co-operating side parameters are limited. The traditional use of 'Kokolmeka roja' for many generations proves that the intake of this remedy is safe and the healing properties prevail over potential adverse effects. 
Although it is generally used against inflammatory ailments, in the present study we have shown that the rhizome of $S$. spinosa exhibits significant potential as anti-neoplastic concept and should therefore be tested in vivo.

\section{Acknowledgements}

We thank Toni Jäger who helped prepare the figures. The Funds for Innovative Interdisciplinary Cancer Research to G.K. provided financial support. The Austrian Exchange Service (OeAD) provided a fellowship to K.J.

\section{References}

1. Pecorino L: Molecular Biology of Cancer. 2nd edition. Oxford University Press, New York, NY, 2008.

2. Stewart BW and Kleihues P: World Cancer Report. IARC Press, Lyon, 2003.

3. Cragg GM and Newman DJ: Plants as a source of anti-cancer agents. J Ethnopharmacol 100: 72-79, 2005.

4. Fabricant DS and Farnsworth NR: The value of plants used in traditional medicine for drug discovery. Environ Health Perspect 109: 69-75, 2001

5. Rastogi RP and Dhawan BN: Research on medicinal plants at the Central Drug Research Institute, Lucknow (India). Indian J Med Res 76: 27-45, 1982

6. Cseke LJ: Natural products from plants. 2nd edition. CRC Press Taylor and Francis, Boca Raton, FL, 2006.

7. Shoeb M: Anticancer agents from medicinal plants. Bangladesh J Pharmacol 1: 35-41, 2006.

8. Kundu JK and Surh YJ: Inflammation: gearing the journey to cancer. Mutat Res 659: 15-30, 2008.

9. Taylor L: The Healing Power of Rainforest Herbs: A Guide to Understanding and Using Herbal Medicinals. Square One Publishers, New York, NY, 2005.

10. Caceres A, Cano O, Samayoa B and Aguilar L: Plants used in Guatemala for the treatment of gastrointestinal disorders. 1. Screening of 84 plants against enterobacteria. J Ethnopharmacol 30: $55-73,1990$

11. Jiang $\mathrm{J}$ and $\mathrm{Xu} \mathrm{Q}$ : Immunomodulatory activity of the aqueous extract from rhizome of Smilax glabra in the later phase of adjuvant-induced arthritis in rats. J Ethnopharmacol 85: 53-59, 2003.

12. Alam MI and Gomes A: Adjuvant effects and antiserum action potentiation by a (herbal) compound 2-hydroxy-4-methoxy benzoic acid isolated from the root extract of the Indian medicinal plant 'sarsaparilla' (Hemidesmus indicus R. Br.). Toxicon 36: 1423-1431, 1998

13. Navarro MC, Montilla MP, Cabo MM, Galisteo M, Cáceres A Morales $\mathrm{C}$ and Berger I: Antibacterial, antiprotozoal and antioxidant activity of five plants used in Ibazal for infectious. Phytother Res 17: 325-329, 2003.

14. Arvigo R and Balick M: Rainforest Remedies. One Hundred Healing Herbs of Belize. 2nd edition, Lotus Press, Twin Lakes, WI, pp72-73, 1998.

15. Gridling M, Stark N, Madlener S, Lackner A, Popescu R, Benedek B, Diaz R, Tut FM, Nha Vo TP, Huber D, et al: In vitro anti-cancer activity of two ethno-pharmacological healing plants from Guatemala Pluchea odorata and Phlebodium decumanum. Int J Oncol 34: 1117-1128, 2009.

16. Stark N, Gridling M, Madlener S, Bauer S, Lackner A, Popescu R, Diaz R, Tut FM, Vo TP, Vonach C, et al: A polar extract of the Maya healing plant Anthurium schlechtendalii (Aracea) exhibits strong in vitro anticancer activity. Int J Mol Med 24: 513-521, 2009 .

17. Strasser S, Maier S, Leisser C, Saiko P, Madlener S, Bader Y, Bernhaus A, Gueorguieva M, Richter S, R. Mader RM, et al: 5-FdUrd-araC heterodinucleoside re-establishes sensitivity in 5-FdUrd- and AraC- resistant MCF-7 breast cancer cells overexpressing ErbB2. Differentiation 74: 488-498, 2006.

18. Maier S, Strasser S, Saiko P, Leisser C, Sasgary S, Grusch M, Madlener S, Bader Y, Hartmann J, Schott H, et al: Analysis of mechanisms contributing to AraC-mediated chemoresistance and re-establishment of drug sensitivity by the novel heterodinucleoside phosphate 5-FdUrd-araC. Apoptosis 11: 427-440, 2006.
19. Hüttenbrenner S, Maier S, Leisser C, Polgar D, Strasser S, Grusch M and Krupitza G: The evolution of cell death programs as prerequisites of multicellularity. Rev Mutat Res 543: 235-249, 2003.

20. Grusch M, Fritzer-Szekeres M, FuhrmannG, Rosenberger G, Luxbacher C, Elford HL, Smid K, Peters GJ, Szekeres T and Krupitza G: Activation of caspases and induction of apoptosis by amidox and didox. Exp Haematol 29: 623-632, 2001.

21. Madlener S, Rosner M, Krieger S, Giessrigl B, Gridling M, Vo TP, Leisser C, Lackner A, Raab I, Grusch M, et al: Short 42 degrees $\mathrm{C}$ heat shock induces phosphorylation and degradation of Cdc25A which depends on p38MAPK, Chk2 and 14.3.3. Hum Mol Genet 18: 1990-2000, 2009.

22. Kastan MB and Bartek J: Cell-cycle checkpoints and cancer. Nature 432: 316-323, 2004

23. Blomberg I and Hoffmann I: Ectopic expression of Cdc25A accelerates the $\mathrm{G}(1) / \mathrm{S}$ transition and leads to premature activation of cyclin E- and cyclin A-dependent kinases. Mol Cell Biol 19: 6183-6194, 1999

24. Kiyokawa H and Ray D: In vivo roles of CDC25 phosphatases biological insight into the anti-cancer therapeutic targets. Anticancer Agents Med Chem 8: 832-836, 2008.

25. Meeran SM and Katiyar SK: Cell cycle control as a basis for cancer chemoprevention through dietary agents. Front Biosci 13: 2191-2202, 2008.

26. Wolf D and Rotter V: Major deletions in the gene encoding the p53 tumor antigen cause lack of p53 expression in HL-60 cells. Proc Natl Acad Sci USA 82: 790-794, 1985.

27. Abukhdeir AM and Park BH: P21 and p27: roles in carcinogenesis and drug resistanc. Expert Rev Mol Med 10: e19, 2008

28. Coller HA, Grandori C, Tamayo P, Colbert T, Lander ES, Eisenman RN and Golub TR: Expression analysis with oligonucleotide microarrays reveals that MYC regulates genes involved in growth, cell cycle, signaling, and adhesion. Proc Natl Sci USA 97: 3260-3265, 2000.

29. Chang C, Zhu YQ, Mei JJ, Liu SQ and Luo J: Involvement of mitochondrial pathway in NCTD-induced cytotoxicity in human hepG2 cells. J Exp Clin Cancer Res 29: 145-154, 2010.

30. Paull TT, Rogakou EP, Yamazaki V, Kirchgessner CU, Gellert M and Bonner WM: A critical role for histone $\mathrm{H} 2 \mathrm{AX}$ in recruitment of repair factors to nuclear foci after DNA damage. Curr Biol 10: 886-895, 2000

31. Piperno G, LeDizet $\mathrm{M}$ and Chang J: Microtubules containing acetylated alpha-tubulin in mammalian cells in culture. J Cell Biol 104: 289-302, 1987.

32. Jackson CB and Giraud AS: Stat 3 as a prognostic marker in human gastric cancer. J Gastroenterol Hepatol 24: 505-507, 2009.

33. Kanda N, Seno H, Konda Y, Marusawa H, Kanai M, Nakajima T, Kawashima T, Nanakin A, Sawabu T, Uenoyama Y, et al: Stat3 is constitutively activated and supports cell survival in association with survivin expression in gastric cancer cells. Oncogene 23: 4921-4929, 2004

34. Gritsko T, Williams A, Turkson J, Kaneko S, Bowman T, Huang M, Nam S, Eweis I, Diaz N, Sullivan D, et al: Persistent activation of stat 3 signaling induces survivin gene expression and confers resistance to apoptosis in human breast cancer cells. Clin Cancer Res 12: 11-19, 2006.

35. Deng JY, Sun D, Liu XY, Pan Y and Liang H: Stat-3 correlates with lymph node metastasis and cell survival in gastric cancer. World J Gastroenterol 16: 5380-5387, 2010.

36. Zhao M, Jiang B and Gao FH: Small molecule inhibitors of STAT3 for cancer therapy. Curr Med Chem 18: 4012-4018, 2011.

37. Gündogdu MS, Liu H, Metzdorf D, Hildebrand D, Aigner M, Aktories K, Heeg K and Kubatzky KF: The haematopoietic GTPase RhoH modulates IL3 signalling through regulation of Stat activity and IL3 receptor expression. Mol Cancer 9: 225-238, 2010.

38. Jinawath N, Va,soontara C, Jinawath A, Fang X, Zhao K, Yap KL, Guo T, Lee CS, Wang W, Balgley BM, et al: Oncoproteomic analysis reveals co-upregulation of RELA and Stat5 in carboplatin resistant ovarian carcinoma. PLoS One 5: e11198, 2010.

39. Dominguez-Sola D, Ying CY, Grandori C, Ruggiero L, Chen B, Li M, Galloway DA, Gu W, Gautier J and Dalla-Favera R: Non-transcriptional control of DNA replication by c-Myc. Nature 448: 445-451, 2007.

40. Wang H, Birkenbach M and Hart J: Expression of Jun family members in human colorectal adenocarcinoma. Carcinogenesis 21: $1313-1317,2000$ 
41. Mathiasen DP, Egebjerg C, Andersen SH, Rafn B, Puustinen P, Khanna A, Daugaard M, Valo E, Tuomela S, Bøttzauw T, et al: Identification of a c-Jun N-terminal kinase-2-dependent signal amplification cascade that regulates c-Myc levels in ras transformation. Oncogene 31: 390-401, 2012.

42. Ivanova A, Mikhova B, Klaiber I, Dinchev D and Kostova I: Steroidal saponins from Smilax excelsa rhizomes. Nat Prod Res 23: 916-924, 2009

43. Doyle BJ, Frasor J, Bellows LE, Locklear TD, Perez A, GomezLaurito J and Mahady GB: Estrogenic effects of herbal medicines from Costa Rica used for the management of menopausal symptoms. Menopause 16: 748-755, 2009.

44. Yu Z, Hu D and, Li Y: Effects of zearalenone on mRNA expression and activity of cytochrome P450 1A1 and 1B1 in MCF-7 cells. Ecotoxicol Environ Saf 58: 187-193, 2004.

45. Sergentanis TN and Economopoulos KP: Four polymorphisms in cytochrome P450 1A1 (CYP1A1) gene and breast cancer risk: a meta-analysis. Breast Cancer Res Treat 122: 459-469, 2010 .
46. Sergentanis TN and Economopoulos KP: Erratum to: Four polymorphisms in cytochrome P450 1A1 (CYP1A1) gene and breast cancer risk: a meta-analysis. Breast Cancer Res Treat 131: 1083, 2012.

47. Kozak W, Mayfield KP, Kozak A and Kluger MJ: Proadifen (SKF525A), an inhibitor of cytochrome P-450, augments LPS-induced fever and exacerbates prostaglandin-E2 levels in the rat. J Therm Biol 25: 45-50, 2000.

48. Sun J, Sui X, Bradbury JA, Zeldin DC, Conte MS and Liao JK: Inhibition of vascular smooth muscle cell migration by cytochrome p450 epoxygenase-derived eicosanoids. Circ Res 90: 1020-1027, 2002. 